\title{
MOŽNOSTI PŘIŘAZENÍ PŘEDMĚTŮ Z ODPADNÍCH JÍMEK V PLZNI KONKRÉTNÍM OBYVATELŮM MĚSTA
}

\author{
JIŘÍ ORNA - VERONIKA DUDKOVÁ
}

\begin{abstract}
Abstrakt: Příspěvek nastiňuje možnosti přrirazení předmětů nalezených v zásypu odpadních jimek v Plzni konkrétním obyvatelüm města v obdobi pozdního středověku a časného novověku. Především s pomocí pisemných pramenư se podařilo $v$ deviti prípadech najít artefakty nebo skupiny artefaktü, které mély přimou vazbu na konkrétniho majitele domu, poprípadě alespoň určit řemeslo či živnost, která byla vobjektu s př́slušnou jímkou provozována. Na základě pozitivních zjištění byly následně definovány kategorie, které umožnily identifikaci konkrétní osoby, a také výčet komplikací, které naopak tuto činnost ztěžuji.
\end{abstract}

Klíčová slova: Plzeň - odpadní jímky - remesla - písemné prameny - heraldika.

\section{Possible Attribution of Items from Refuse Pits in Plzen̆ to Particular Inhabitants of the Town}

Abstract: This article outlines the possibilities of the attribution of items found in the fills of refuse pits in Plzeñ to particular inhabitants of this town in the late Middle Ages and the early modern age. With the help of written sources it was possible, in nine cases, to find artefacts and groups of artefacts that were directly linked to concrete house owners, or at least to determine the crafts practised in houses with particular refuse pits. On the basis of positive findings, categories that enabled the identification of concrete persons were subsequently defined, as well as complications hampering this activity.

Key words: Plzeñ - refuse pits - crafts - written sources - heraldry.

\section{Úvod}

Dlouholetý archeologický výzkum studní a odpadních jímek související především se sanačními úpravami prostor plzeňského podzemí umožnil vytvoření kvantitativně i kvalitativně výrazného nálezového fondu. Tento obsáhlý a ve středoevropském kontextu poměrně unikátní fond byl v průběhu let zpracováván v rámci nejrůznějších publikačních výstupů. Kompletně se tímto způsobem podařilo zprrístupnit pouze nálezové soubory z odpadních jímek zkoumaných při archeologických výzkumech parcel čp. 187 (Nováček 2000) a čp. 262 (Nechvátal 1976) a ve sklepě domů čp. 66/67 (Schneiderwinklová a kol. 2008; Schneiderwinklová 2009). Mnohem větší pozornosti se dostalo nálezům z těchto zahloubených objektů. Nejkomplexnější publikační činností prošly skleněné (Frýda 1979; 1990; 2007; Černá a kol. 1994), dřevěné (Frýda 1983; Orna 2000) a textilní (Březinová 2007) artefakty. Publikace keramických nálezů se soustředila na zajímavější produkty hrnčířské výroby - celé nádoby (Orna a kol. 2011), kachle (Orna 2005), akvamanilie (Hus 1991), drobnou figurální plastiku (Orna 2006) a zvonky (Orna 2002). Zpracovány byly také unikátní nálezy - skupiny artefaktů související s osobní hygienou v plzeňských domácnostech (Dudková-Orna 2013), s provozováním lékařské a lékárenské profese (Dudková-Orna 2009) a polychromovaná zlacená plastika v podobě vztyčeného lva držícího erbovní štít (Frýda 2011).

\section{Možnosti identifikace majitelů předmětů na základě písemných pramenů}

Poslední dvě uvedené studie prokázaly, že u některých artefaktů nalezených v odpadních jímkách je možné především s využitím písemných pramenů jejich přiřazení konkrétním obyvatelům tehdejší Plzně. Proto byla provedena revize sbírkového fondu s cílem vyhledat další nálezy s podobným potenciálem, tedy s možností dohledat osobu, ke které měly přímý vztah, popřípadě alespoň určit řemeslo či živnost, která byla v objektu s př́íslušnou jímkou provozována. Na základě př́ípadných pozitivních zjištění by následně bylo možné definovat kategorie, které umožňují identifikaci konkrétní osoby, a také podat výčet komplikací, které naopak tuto činnost ztěžují. 
Při zkoumání období vrcholného středověku a následných mladších období se archeologie bez písemných pramenů a historických výzkumů neobejde. U písemných pramenů je největším problémem jejich dochování, jen zřídka se pamětní knihy, berní prameny, závěti a různá statuta dochovají v ucelených řadách. Ke zkreslení informací u prací využívajících písemné prameny může dojít při jejich interpretaci.

Propojení a komparace archeologických a historických pramenů nabízí další možnosti poznávání každodenního života, v tomto případě v přímé vazbě na konkrétní osobu, či na danou skupinu obyvatel (napřx. prŕśslušníky nějakého řemesla). Tato možnost, jak propojit poznání získaná z písemných a archeologických pramenů, doplňuje mozaiku poznání života v pozdně středověkém a novověkém městě. Na téma propojení písemných a historických pramenů bylo vedeno množství diskusí již od druhého desetiletí 20. století, kdy Václav Novotný vydal své České dějiny (1912), v jejichž úvodním programovém prohlášení podrobil kritice informační možnosti a využitelnost archeologických pramenů pro historické bádání (Klápště 2003, 96). Do debaty o možnostech využití archeologických pramenů historií a v pozdějších obdobích hlavně o vzájemném vztahu a střetávání se obou věd se zapojili především E. Neustupný (2002), N. a M. Profantovi (2003), D. Třeštík (2001) a J. Klápště (2003). Většina problémů, které definují

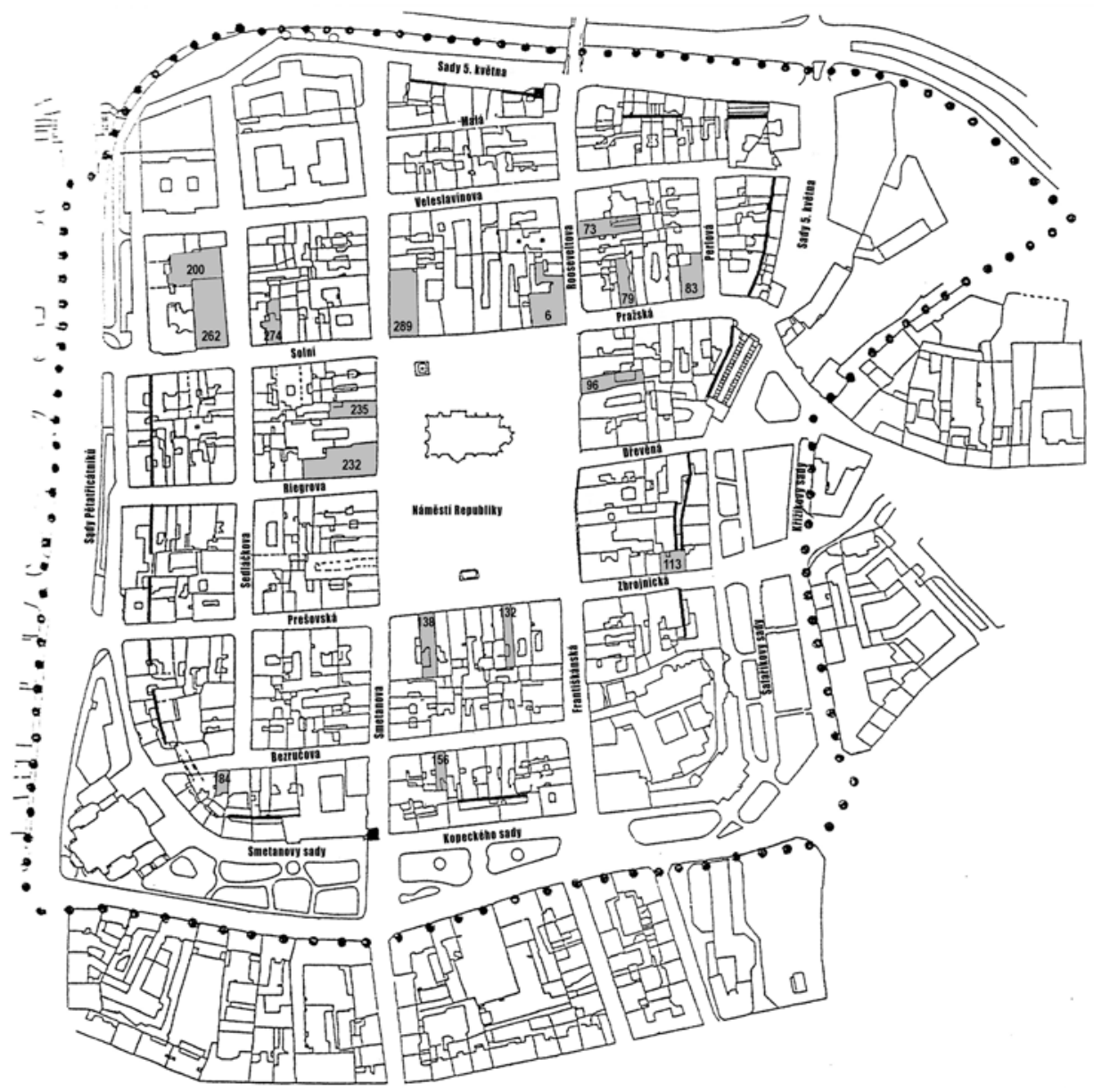

Obr. 1. Plzeň. Celkový plán historického centra města s vyznačením lokalit uvedených v textu. Úprava V. Lungová.

Abb. 1. Pilsen. Gesamtplan des historischen Stadtzentrums mit eingezeichneten, im Text genannten Fundstellen. Bearbeitung von V. Lungová. 
jako překážky ve smysluplné komunikaci mezi historií a archeologií, se dá vztáhnout i na téma této studie - tj. na problematiku zosobnění (personifikace) archeologického nálezu. V případě pramenů archeologických je zřejmě největším omezením to, že většina nalezených předmětů je svým vzhledem, materiálem i použitím příliš univerzální, postrádají specifičnost - jejich vlastníkem mohl být téměř kdokoliv, a tak v podstatě o svém majiteli nic nevypovídají. Abychom tedy byli schopni dát do souvislosti konkrétní předmět s konkrétní osobou, musí jít o předmět, který již ve své vlastní existenci skrývá přímou vazbu na tuto osobu. Nezřídka jde tudíž o předměty vyrobené na zakázku. Z celkového počtu nalezených předmětů je ovšem tímto způsobem identifikovatelná jen velmi malá část.

O něco odlišnější je pak vypovídací schopnost předmětů, které umožňují zařadit vlastníka/ uživatele předmětu do jasně definované skupiny obyvatel. V tomto případě nemusí nutně jít pouze o př́ípady příslušníků cechů řemesel, ale např. i o skupiny odlišující se od majority náboženstvím, národností či etnicitou (napřx. protestanté, či židovské etnikum). Souvislost s takovouto konkrétní skupinou osob může mít zpravidla širší škála artefaktů, a to samozřejmě zvyšuje možnost přiřazení nálezu k jednotlivé osobě, která byla součástí této skupiny. (Například zmiňované skupiny řemeslníků můžeme identifikovat na základě surovin, nástrojů, polotovarů, výrobků, ale i výrobního odpadu - v těchto prŕípadech pak může být důležitá i kvantita nalezených artefaktů, která svědčí o systematické činnosti po delší časový úsek.)

Dalším omezením, které s sebou archeologické prameny nesou, je často příliš široký interval datování. Ten sice nemusí být zásadní překážkou kooperace archeologie a historie pro studium dlouhodobějších jevů na pozadí událostí politických dějin (Klápště 2003, 100-101), ale při přiřazování konkrétního předmětu ke konkrétnímu vlastníkovi může být leckdy na překážku.

Také místo nálezu nemusí být $\mathrm{v}$ některých případech zcela signifikantní, ne vždy je zcela jasné, $v$ jaké vazbě je místo nálezu $\mathrm{k}$ původnímu místu užívání (charakteristické jsou např. nálezy kachlů v druhotných polohách v destrukčních či spáleništních vrstvách, např. Dudková-Orna 2007).

\section{Přehled odpadních jímek s pozitivním zjištěním}

\section{Čp. 6, odpadní jímka}

Nalezené polotovary dvou dřevěných pohrabel a hoblíku (Orna 2000) naznačují, že do zásypu jímky se dostal odpad z dřevozpracující výroby, nebot' pohrabla byla do požadovaného tvaru zpravidla vysoustružena. V písemných pramenech však postrádáme doklady činnosti takto zaměřeného řemeslníka.

\section{Čp. 73, odpadní jímka 1}

Nalezené předměty - sedátko stoličky, víko truhly, opěradlo lavice, nůž soustruhu (Orna 2000) - lze spojit s výrobou či opravou nábytku. Ani v tomto př́ípadě se nepodařilo v písemných pramenech identifikovat řemeslníka.

\section{Čp. 79, odpadní jímka}

V zásypu tohoto objektu se nalezly podrážky a svršky kožených škorní, včetně dětských, a pláty kůží s otvory po šití a pro provlečení řemínku nebo tkanice. Těchto 26 nalezených fragmentů je možné označit za doklad výroby obuvi. Součástí zásypu této odpadní jímky bylo též 32 fragmentů z 15 různých vlněných tkanin (Březinová 2007, 48). Z polohopisného zaměření (obr. 2) dotčené jímky je evidentní, že patřila k sousednímu čp. 80. Jímka je situována pod stěnou domu, což je časté umístění fekálních jímek (Dudková-Orna 2013, 559). Tento dům v 16. století vlastnili většinou ševci, roku 1564 ho Matouš Korbel zakoupil za 345 kop, v roce 1583 Jan Fousek za 470 kop (Macháček 1931, 141). 


\section{Čp. 83, odpadní jímky}

Také zde se vyskytl početný soubor textilií, 19 fragmentů z 19 různých vlněných tkanin (Březinová 2007, 46, 48). V roce 1423 se majitelem domu stal švec Henslík (Strnad 1909, 79).

\section{$\check{C}$ p. 96}

Řada kožených artefaktů byla získána ze zásypu odpadní jímky v tomto domě. Poměrně marginálně se vyskytují části bot (6 kusů). Podařilo se získat zbytky dvou brašen, množství odřezků řemenů a pásků (59 kusů). Složení tohoto souboru kožených artefaktů odpovídá řemeslu majitele domu na přelomu 14. a 15. století, kterým byl sedlář Petr Snorl (Strnad 1909, 61).

\section{Čp. 232, odpadní jímka 2}

V zásypu tohoto zahloubeného objektu se podařilo zachytit velké množství (více než 200 kusů) odhozených součástí bot, odřezaných z používaných kusů poškozených prošlapáním, prodřením nebo roztržením. Ty v tomto objektu tvoři $80 \%$ ze všech vytěžených kůží. Autor výzkumu uložení tohoto výrobního odpadu spojuje s činností ševce (Frýda 1981, 314), která však zřejmě nebyla dlouhodobá (Frýda 1981, 318). Zásyp obsahoval také 38 textilií (Březinová 47, tab. I).

Lokalizace této odpadní jímky (obr. 3) vylučuje možnost, že by byla využívána ševci působícími v průběhu 16. století v čp. 233 (Macháček 1931, 88) a čp. 246 (Macháček 1931, 94). Podle výplně (Frýda 1981, 9) i situování u severní stěny domu čp. 229 šlo o jímku fekální. Ty se velmi často vyskytují právě u stěny domu, případně pod ní (Dudková-Orna 2013, 559). Přímá vazba na objekt čp. 229 naznačuje, že uživatele odpadní jímky je třeba hledat mezi majiteli tohoto objektu. Ty však až na jednu výjimku v období pozdního stř̌edověku a časného novověku neznáme (Strnad 1909, 70-71; Macháček 1931, 87).

\section{Čp. 262, odpadní jímka}

Byl vyzvednut soubor 42 kusů kůží tvořený různými částmi obuvi, řemínky a pásky a neurčitelnou částí oděvu (Nechvátal 1976, 77-80, 117, obr. 56-60). Z tohoto objektu byl také získán největší a nejlépe zpracovaný soubor středověkých textilií datovaný do první poloviny 15 . století, jehož naprostou většinu tvoří vlněné tkaniny, vyráběné z místních i importovaných surovin. Unikátem jsou hedvábné tkaniny ze zahraničních textilních dílen (Březinová 2007, 46). Ukládání výplně odpadní jímky bylo autorem výzkumu datováno - na základě rozboru keramického materiálu - do období od konce 14. století do průběhu první poloviny 15. století (Nechvátal 1976, 127). Pro toto období v písemných pramenech neexistují přímé zmínky o řemeslnících, k jejichž činnosti by bylo možné vztáhnout výše uvedené nálezy. Na parcele tehdy stály dva domy, majitelem rohového se v roce 1409 stal vozataj Mikuláš, který jej roku 1424 prodal sladovníkovi Tomcovi, druhý z domů držel do roku 1409 žid Hesl, poté se stal majitelem žid Dobrý (Strnad 1909, 72). 


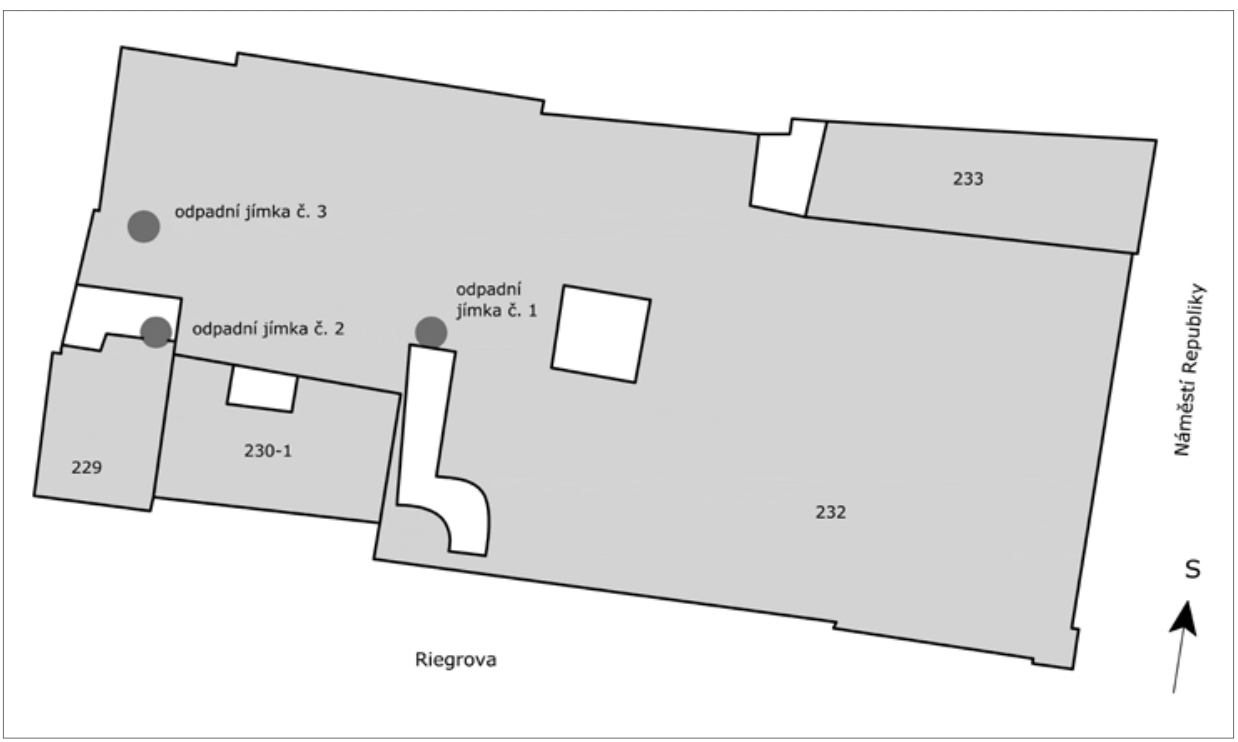

Obr. 3. Plzeň, čp. 232. Odpadní jímky - polohopisné zaměření. Úprava V. Lungová.

Abb. 3. Pilsen, Konskriptionsnr. 232. Abwassergruben - Lageplanvermessung. Bearbeitung V. Lungová.

\section{Čp. 289, odpadní jímka}

Již zmíněný nález polychromované zlacené plastiky v podobě vztyčeného lva držícího erbovní štít (obr. 4) byl vyzvednut ze zásypu této jímky. Pravděpodobně jde o kamnový vrcholový nástavec. Ve štítě je heraldicky vpravo vyobrazena labut's rozepjatými kř́idly, stojící na větvi a v zobáku držící vavřínový věnec. Toto znamení (obr. 5) používali bratři Jan a Kašpar Kropáčové od roku 1560, kdy se stali erbovními měštany (Strnad 1898, 268). Díky svatbě v roce 1564 Kašpar Kropáč z Kozince, přední humanista a významný latinsky píšící básník (Felix 1930, 35-38; Frýda 2011, 88-90; Strnad 1898), získal rozsáhlý majetek, včetně domu čp. 289, který mu roku 1573 manželka věnovala (Strnad 1898, 270). Majitelem zůstal až do své smrti 13. ledna 1580 (Hruška 1883, 103).

Nalezená plastika tedy zcela jistě zdobila interiér domu v době, kdy jej Kašpar Kropáč z Kozince obýval, tj. někdy v rozmezí let 1563-1579. Její vznik je kladen do let 1565-1567, kdy došlo k renesanční přestavbě domu (Frýda 2011, 90).

\section{Čp. 289, odpadní jímka}

Tato jímka patří mezi ty nálezově nejbohatší. Podle nalezených artefaktů je možné konstatovat, že výplň byla do jímky ukládána zhruba od poloviny 16. do druhé poloviny 17. století (Frýda 1983a). Vedle výše uvedené plastiky byla součástí jejího zásypu celá řada artefaktů souvisejících s provozováním lékařské a lékárenské profese (kromě kameninových i keramické dózičky, kameninové a skleněné lahvičky, laboratorní sklo, skalpel, prubířské kameny, skleněný emailovaný pohár s motivem Aeskulapovy hole; Dudková-Orna 2009). Na základě písemných zpráv je možné tyto nálezy dát do souvislosti s působením Martina Leybringera, který se stal majitelem domu v roce 1643 a „,...) byl nejspiše felčarem stejně, jako jistě byl chirurgem druhý manžel jeho vdovy Hons Michl Payer" (Macháček 1931, 123). Payer byl také lazebníkem, v domě tedy fungovaly lázně. Dům poté zdědil M. Václav Sypský, manžel vdovy po Payerovi. V roce 1696 zde byl vykázán kvartýr novému krajskému hejtmanu hraběti Ferdinandu z Morzinu (Macháček 1931, 123, 124). 


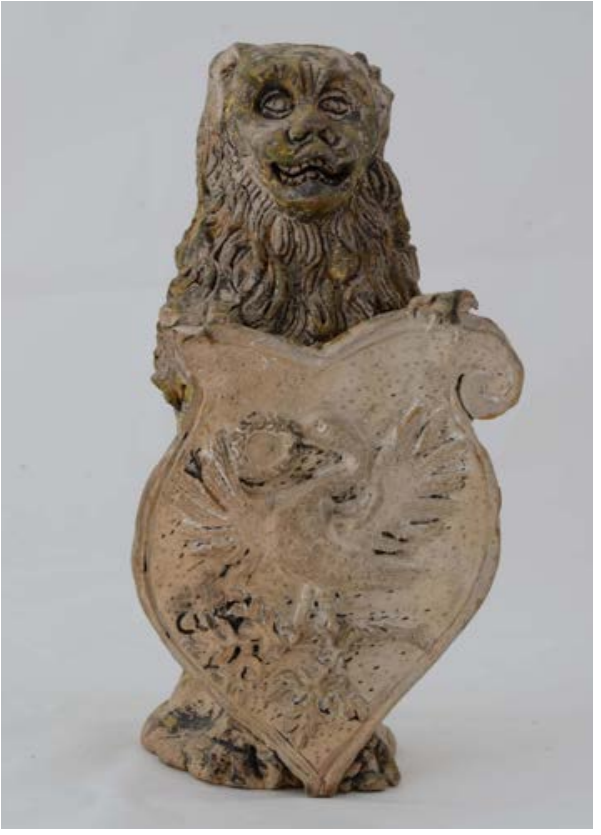

Obr. 4. Plzeň, čp. 289. Odpadní jímka - plastika. Foto I. Michnerová.

Abb. 4. Pilsen, Konskriptionsnr. 289. Abwassergrube Skulptur. Foto I. Michnerová.

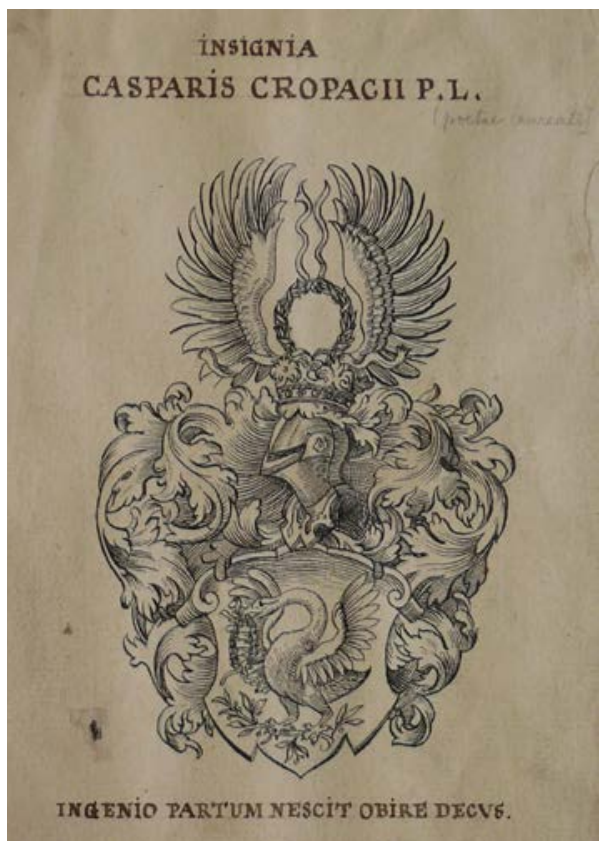

Obr. 5. Erb Kropáčů z Kozince.

Abb. 5. Wappen der Familie Kropáč von Kozinec.

\section{Definice kategorií umožňujících identifikaci konkrétní osoby}

\section{Heraldická znamení}

Vzhledem $\mathrm{k}$ tomu, že v Plzni v období 16. a 17. století působila celá řada erbovních měštanů (Rybička 1874), je trochu s podivem, že dosud byl zaznamenán pouze jeden nález s nimi související, a to plastika s erbem Kašpara Kropáče z Kozince. Takto nízký počet dokladů erbovních měšt’anů spíše než s jejich skromností souvisí s výraznou redukcí nálezového fondu při obrovském stavebním boomu ve druhé polovině 19. století a první polovině 20. století, kdy proběhly výrazné stavební úpravy u zhruba $75 \%$ domů situovaných v historickém jádru města. Zmíněná redukce se zcela jistě týkala také komorových kachlů (Orna 2005, 146), na jejichž čelních výhřevných stěnách si lze tato erbovní znamení představit.

Heraldické znaky nese také džbán chronologicky zařaditelný na sklonek 14. století vyzvednutý z odpadní jímky v čp. 113 ve Zbrojnické ulici. Nádoba je zdobena třemi kolky (obr. 6). Dva z nich nesou zemské znaky - dvouocasého korunovaného lva a orlici. Třetí kolek nese motiv kozorožce nebo kozla. Vyobrazení těchto zvířat jsou na heraldických znameních poměrně častá (Koláŕ-Sedláček 1902, 178). Lze předpokládat, že nádoba s takto specifickou výzdobou musela být vyrobena na zakázku, a zadavatel tedy musel mít k tomuto znamení nějaký vztah. Odpadní jímka u čp. 113 byla zřejmě volně př́istupná i z domů čp. 106-109 (obr. 7). Pro konec 14. století nám však pro všechny zmíněné objekty chybí zprávy o majitelích. Určitou indicií by mohla být informace, že v domě čp. 106 sídlila radnice, $\mathrm{v}$ písemných pramenech prvně zmíněná v roce 1415 (Strnad 1909, 62). Užívání tohoto džbánu si lze spíše představit v prostorách radnice než u domu u městské hradby, jakým bylo čp. 113.

Z nálezů nepocházejících z odpadních jímek je možné zmínit dlaždici získanou L. Lábkem při rekonstrukci domu čp. 274. V literatuře byla její výzdoba označena za geometrický 

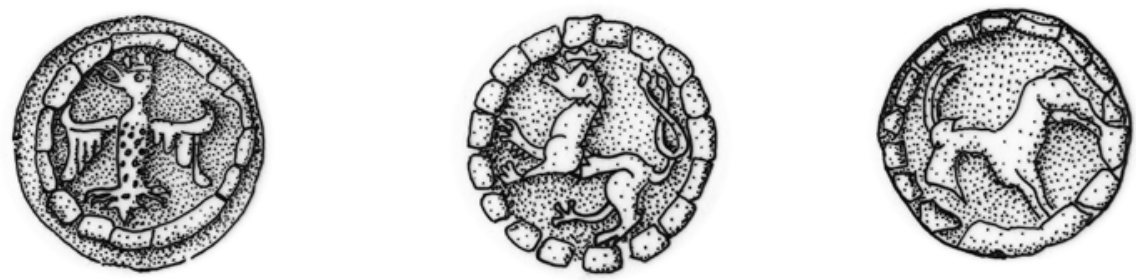

Obr. 6. Kolky s heraldickými symboly. Kresba V. Dudková.

Abb. 6. Stempelmarken mit heraldischen Symbolen. Zeichnung V. Dudková.

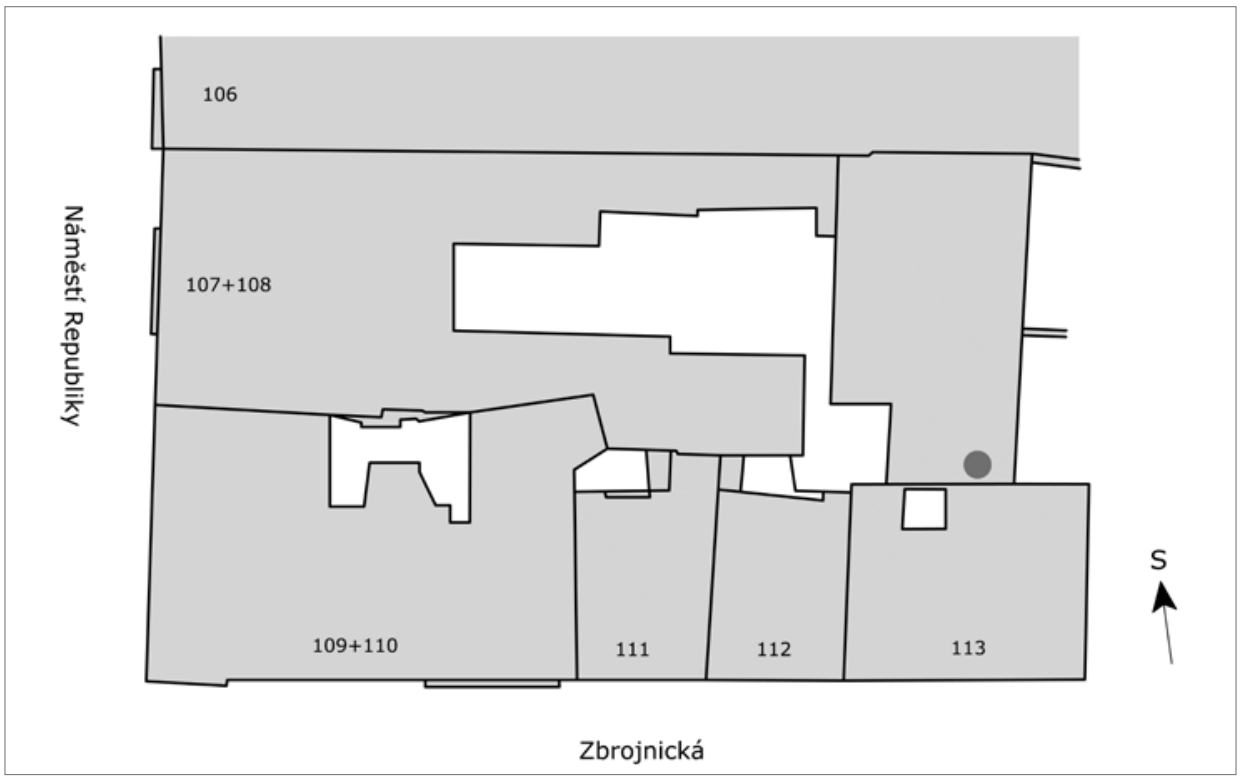

Obr. 7. Plzeň, čp. 113. Odpadní jímka - polohopisné zaměření. Úprava V. Lungová.

Abb. 7. Pilsen, Konskriptionsnr. 113. Abwassergrube - Lageplanvermessung. Bearbeitung V. Lungová.

motiv (Frýda-Stehlíková 1995, 552, kat. č. 174, obr. 716). Vzhledem k tomu, že další tři dlaždice získané z této lokality nesou figury plzeňského znaku z let 1434-1466 (Frýda-Stehlíková 1995, 552, kat. č. 174, obr. 716; Nechvátal 1984, 257, obr. 12; Orna-Dudková 2012, 167), je možné obrazec na reliéfu dlaždice (obr. 8) označit za erb majitele domu, výtvarně nepř́lilš kvalitně propracovaný. Pro období okolo poloviny 15 . století však chybí údaje o majitelích domu. $\mathrm{V}$ roce 1410 jej zakoupil kameník Hanuš z Jindřichova Hradce (Strnad 1909, 75), další údaj se pak vztahuje až k roku 1653 (Macháček 1931, 105).

Obr. 8. Plzeň, čp. 274. Dlaždice získaná při rekonstrukci domu. Foto M. Zemánková.

Abb. 8. Pilsen, Konskriptionsnr. 274. Bei der Renovierung eines Hauses entdeckte Fliese. Foto M. Zemánková.

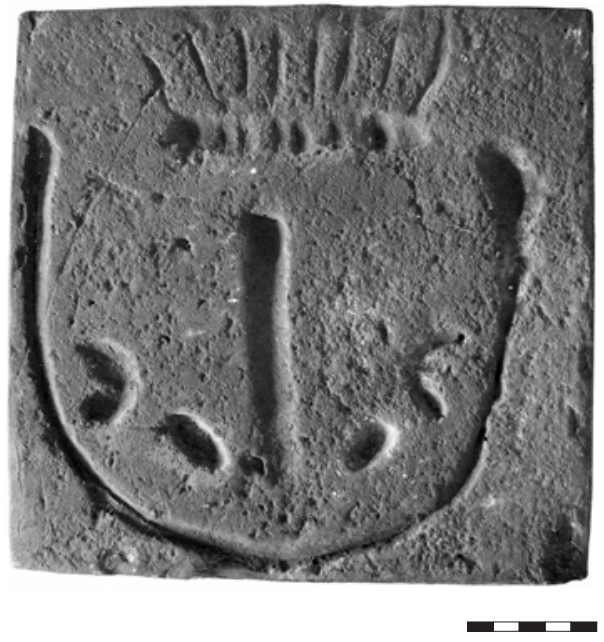




\section{Vybavení potřebné k provozování řemesla či živnosti}

Do této skupiny patři nálezy artefaktů souvisejících s provozováním lékařské či lékárenské profese, v Plzni doložené především nálezy z odpadní jímky u čp. 289. Jejich určení umožnily analogie z jiných lokalit (např. Huml 1995; Neugebauer 1965) a ikonografické prameny (Svobodný-Hlaváčková 2004; Rusek-Smečka 2000). Souběžné vykonávání lékařské i lékárenské praxe nebylo v období pozdního středověku a časného novověku ničím neobvyklým (Svobodný-Hlaváčová 2004, 50; Rusek-Smečka 2000, 45, 50).

Z mladších období 18. a 19. století se doklady provozu lékárny podařilo získat z klenebních zásypů v čp. 96 (Dudková-Orna 2012) a při výzkumu objektu čp. 138.

K vybavení potřebnému k provozování řemesla patří i nůž soustruhu nalezený v odpadní jímce 1 u čp. 73.

S realizací druhých sklepů i odpadních jímek souvisí nálezy hornických neciček (Orna 2000) a značně opotř̌ebovaná hlavice železného havířského mlátku na dřevěné zkrácené násadě nalezená v odpadní jímce u čp. 132. Oba ty to artefakty mohou souviset se specializovanou činností, jakou bylo nejen hloubení jímek (Nováček-Stočes-Široký-Wasková 2014, 158), ale také budování především druhého patra sklepů. Vzhledem k požadavku na specializaci řemeslníka však tyto nálezy nemají př́mou souvislost s majitelem domu.

\section{Výrobní odpad}

Předpokládaný potenciál výrobního odpadu tvořeného artefakty z organických materiálů se potvrdil především u kůže. Řemeslníka včetně jména se podařilo určit u dvou objektů (čp. 79 a čp. 96), další dvě ševcovské dílny se podařilo lokalizovat (čp. 232, 262). Kožené artefakty se našly i v dalších odpadních jímkách (čp. 191, čp. 31), nikoli však v takovém množství, aby bylo možné přesvědčivě vyloučit domácí přešívání obuvi, obecně rozšířené v období stř̌edověku (Klápště 2002, 199).

Nálezy textilií z odpadních (fekálních) jímek, především pak malých fragmentů, jsou interpretovány jako hygienická pomůcka plnící stejnou funkci jako současný toaletní papír (Březinová 2007, 95). Takto měly být využity textilní výrobky, které přestaly plnit svůj původní účel, byly proto natrhány, nařezány nebo nastř́hány a použity k intimní potřebě (Tidow 1989, 335).

Stejně jako v Plzni také na jiných lokalitách (Tidow 1989, 335) se textilní fragmenty nacházejí jen v poměrně malém počtu odpadních jímek. V Plzni prošlo archeologickým výzkumem 120 odpadních jímek, zhruba v 80 z nich se podařilo získat ze zásypu artefakty, textilie však byly evidovány pouze ve 12 jímkách, výraznější zastoupení lze potvrdit v polovině z tohoto počtu. Tento fakt je vysvětlován využíváním textilií z rostlinných vláken, které se v agresivním prostředí jímek rozloží, popřípadě jiných materiálů doložených nálezy v odpadních jímkách (např. Čulíková 2002, 151-153).

V této souvislosti je třeba zmínit zjištění, že v plzeňských nálezech se ve třech odpadních jímkách (čp. 79, 232, 262) textilie vyskytly společně s koženým odpadem, a mohou tedy souviset $\mathrm{s}$ působením ševcovské dílny $\mathrm{v}$ těchto objektech. Textilie byly součástí zásypu i v odpadních jímkách u čp. 83, kde je působení ševce doloženo písemnými prameny.

Nevýrazně byl zastoupen odpad dřevozpracujících řemesel. To může souviset s velkou odlesněností okolí Plzně a díky tomu vznikajícími náklady na dovoz a nákup dřeva do města (Nováček 2000, 30).

Doklady řemeslné výroby se však neobjevují pouze v odpadních jímkách. Indicie hrnčířské výroby, odpadní střepniště ze 14. století, byly zachyceny na parcelách při obvodu městského jádra čp. 184, ppč. 200 (Nováček-Široký 2004, 29). V souvrství na parcele čp. 156 byly evidovány doklady kovářského zpracování železa, na parcele čp. 235 metalurgie barevných kovů (Nováček-Široký 2004, 29). Vzhledem k tomu, že poslední informace není podpořena podrobnějším rozborem nálezové situace, je možné jen pro zajímavost zmínit, že v roce 1432 byl dům prodán zlatníku Martinovi (Strnad 1909, 71). 
Prozatím v archeologických i písemných pramenech chybí doklady o dalším řemeslu, z jehož působení vzniká charakteristický výrobní odpad, a to pasířství (Krajíc a kol. 1998, 204-206).

\section{Komplikace při identifikaci konkrétní osoby}

\section{Písemné prameny}

Sociální strukturu středověké a časně novověké Plzně se snaží přiblížit hned několik historiografických studií (Strnad 1909; Macháček 1931; Bělohlávek 1950; 1965; Bělohlávková 1989) vycházejících z dochovaných písemných pramenů. Problémem je neúplné dochování těchto pramenů zejména pro dějiny města $\mathrm{v}$ období pozdního středověku, z kterého pochází nejvíc nálezů v odpadních jímkách, ale také absence kritického přijímání informací (Nováček 2000, 27).

O potřebě kritického př́stupu k písemným pramenům svědčí údaj vztahující se k dnešní Solní ulici. Ta byla ve středověku nazývána Kolářskou (platea rotificum). Při rozboru známých majitelů domů se však ukázalo, že dva z nich drželi kováŕi a dva koláři (Strnad 1909, 71).

\section{Lokalizace odpadních jímek}

Pro identifikaci konkrétní osoby je potřeba lokalizace odpadní či fekální jímky k domu, jehož obyvateli byla využivána. Počátek zděné výstavby kolem roku 1350 (Nováček-Široký 2004, 29) znamenal sice stabilizaci uliční čáry, nadále však docházelo k mnohým změnám parcelace uvnitř bloků domů (Nováček-Široký 2004, 14). Současné přiřazení jímky k čp. tedy nemusí být totožné jako v období, kdy do ní byl ukládán zásyp.

Určité potíže při lokalizaci jímek nastaly při jejich archeologickém výzkumu. Velmi často bylo těleso jímky poškozeno při ražbě chodeb a následně došlo k vybrání zásypu. Mnohdy bylo označení polohy jímky provizorní nebo pouze odhadnuté, nikoli vždy však došlo k upřesnění polohy jímky na základě dokumentace. O složitosti tohoto procesu svědčí i př́iklady uvedené $\mathrm{v}$ předchozím textu, kdy upřesnění lokalizace jímek přiřazených $\mathrm{k}$ čp. 79 a 232 bylo možné až po dohledání jejich vztahu ke konstrukci domu.

\section{Proces deponování odpadu do jímek}

Je známé, že jedna jímka mohla sloužit obyvatelům více domů (Winter 1890, 409). To se projevilo u nálezů souvisejících s působením lékařů v čp. 289, několik artefaktů se objevilo i v odpadní jímce sousedního čp. 288 (Dudková-Orna 2009, 507, obr. 2).

Další komplikací při popisovaných snahách jsou postdepoziční procesy, zejména občasné a částečné čištění jímek doložené výzkumem v čp. 187 (Nováček 2000, 15). Známé jsou však i př́ípady velmi rychlého zaplnění jímek hned po jejich vyhloubení (Nováček-Stočes-Široký-Wasková 2014, 158).

Při konkretizaci osob, které mohly využívat odpadní jímku, je nutné brát v potaz také nájemní bydlení (inquilini) v tzv. zadních domech, o kterém první zachovaná zmínka pochází z roku 1407 (Bělohlávková 1989, 171). Kromě bydlení zde mohlo být provozováno řemeslo či živnost vhodná do těchto podmínek. V úvahu připadají některá dřevozpracující řemesla, jejichž doklady se podařilo zachytit v čp. 6 a 73, avšak v písemných pramenech se př́íslušného výrobce dohledat nepovedlo.

\section{Závěr}

Rozbor nálezů ze zásypu odpadních jímek přináší cenné poznatky k dějinám každodennosti (Iggers 2002, 95-111). Z bohatého nálezového fondu, který byl získán z těchto zahloubených objektů, se podařilo určit devět případů artefaktů nebo skupin artefaktů, které bylo možné dát do přímé souvislosti s majitelem, popř́ípadě uživatelem domu. 
Rozbor těchto pozitivních zjištění umožnil definici kategorií, které posloužily k identifikaci konkrétní osoby. Jednou z nich jsou heraldická znamení, v plzeňském prostředí využitelná zejména pro erbovní měštany v období 16. a 17. století. Bohužel se zatím podařilo evidovat pouze keramickou plastiku s erbem Kašpara Kropáče z Kozince.

Další kategorii tvoří vybavení potřebné k provozování řemesla či živnosti. Živnost - provozování lékařské či lékárenské profese - se včetně určení konkrétních osob podařilo u odpadní jímky v čp. 289. Dokladem dřevozpracujícího řemesla je nůž soustruhu nalezený v odpadní jímce 1 u čp. 73.

Nejčastěji mohl být k určení konkrétní osoby využit výrobní odpad, zejména pak doklady ševcovské a sedlářské činnosti. Rozbor zjištění souvisejících s výrobním odpadem naznačil možnost, že s činností kožedělných řemesel mohou souviset také nálezy textilií.

Výše uvedená zjištění by nebylo možné uskutečnit bez kooperace a komparace s písemnými prameny. Právě jejich absence byla nejvýraznější komplikací při snaze přiřadit archeologický nález konkrétní osobě. Mezi další komplikace patří problém s lokalizací odpadních jímek, který může být důsledkem změn parcelace a nepřesného určení polohy jímky při jejím výzkumu, a proces deponování odpadu do jímek. Jedna jímka mohla sloužit obyvatelům více domů, u každé z nich jinak probíhaly postdepoziční procesy, a využívat je mohly také osoby, které využívaly nájemní bydlení (inquilini) v tzv. zadních domech.

Zjištění učiněná v rámci této studie přispívají zejména k poznání sociální topografie pozdně středověkého a raně novověkého královského města Plzeň. V uvedených př́ikladech archeologické nálezy potvrdily, že provozování řemesla či živnosti probíhalo v nemovitosti vlastněné př́islušným řemeslníkem či živnostníkem, a prokázaly tak pozitivní dopad kooperace a komparace archeologických a historických pramenů pro poznání dějin každodennosti pozdně středověkého a raně novověkého města.

\section{Prameny a literatura}

BĚLOHLÁVEK, M., 1950: Sociální rozvrstvení plzeňského obyvatelstva v roce 1470. In: Život Plzeňska I, 134-138, 157-161. Plzeň.

BĚLOHLÁVEK, M. a kol., 1965: Dějiny Plzně I. Plzeň.

BĚLOHLÁVKOVÁ, J., 1989: Nejstarší dochovaná plzeňská městská kniha soudní z let 1407-1411. In: Sborník archivních prací 39/I, 121-195. Praha.

BŘEZINOVÁ, M., 2007: Textilní výroba v českých zemích ve 13.-15. století. Poznání textilní produkce na základě archeologických nálezů. Dissertationes Archaeologicae Brunenses/Pragensesque 2. Praha - Brno.

ČERNÁ, E. a kol., 1994: Středověké sklo v zemích Koruny české. Katalog výstavy. Most.

ČULÍKOVÁ, V., 2002: Proměny životního prostředí v Mostě podle analýz rostlinných makrozbytků z archeologických situací. In: Archeologie středověkého domu v Mostě (čp. 226) - The archaeology of a medieval House (No. 226) in Most. Mediaevalia archaeologica 4 (Klápště, J., ed.), 136-157. Praha - Most.

DUDKOVÁ, V.-ORNA, J., 2007: Gotické a renesanční kachle z výzkumu horní části náměstí Republiky v Horšovském Týně v roce 2006, SZM XVIII, 217-221.

- 2009: A description of medical equipment in the Early Modern period on the basis of finds from the cesspit at house no. 289 in Plzeň - Obraz vybavení lékaře v novověku na základě nálezů z odpadní jímky v domě č. p. 289 v Plzni - Die Ausstattung eines neuzeitlichen Arztes aufgrund der Funde aus Abfallgrube in Konskr.-Nr. 289 in Pilsen. In: Studies in Post-Medieval Archaeology 3, 501-508. Praha.

- 2012: Written sources and archaeological excavations in Pilsen, Náměstí Republiky no. 97. Písemné prameny a archeologický výzkum v Plzni, Náměstí Republiky čp. 97 - Schriftquellen und die archäologische Grabung in Pilsen, Náměstí Republiky Konskr.-Nr. 97. In: Studies in Post-Medieval Archaeology 4, 419-426. Praha.

- 2013: Osobní hygiena v plzeňských domácnostech na sklonku středověku - Die persönliche Hygiene in Pilsener Haushalten zur Neige des Mittelalters, AH 38, 557-568. Brno.

FELIX, E., 1930: Literární Plzeň v obryse. Od nejstarších dob až do konce XVIII. století. Plzeň.

FRÝDA, F., 1979: Středověké sklo v západních Čechách, SZM - Historie II, 7-78.

- 1981: Hmotná kultura středověkého města na základě výzkumu zasypaných středověkých studní v Plzni. FF UK Praha. Nepublikováno. 
- 1983: Nálezy středověkého dřeva z Plzně - Funde mittelalterlichen Holzes aus Plzeň, AH 8, $287-297$.

- 1983a: Plzeň čp. 289, Dominikánská 2, studna 1. Nálezová zpráva ulož. v archivu odd. starších dějin ZČM v Plzni, čj. 189.

- 1990: Typologie středověkého skla v Čechách od 13. do konce 15. století, SZM - Historie V, 59-84.

- 2007: Nálezy renesančního skla z Plzně - Pilsner Glasfunde aus der Renaissancezeit, Historické sklo. Sborník pro dějiny skla 4, 33-65.

- 2011: Keramická plastika s erbem Kašpara Kropáče z Kozince - Keramischer Aufsatz einer Löwens-Plastik mit Wappen des Kašpar Kropáč aus Kozinec, ČSPS 119, č. 2, 88-91.

FRÝDA, F.-STEHLÍKOVÁ, D., 1995: Umělecká řemesla. In: Gotika v západních Čechách. 1230-1530 (Fajt, J., ed.), 487-570. Praha.

HRUŠKA, M., 1883: Kniha pamětní král. krajského města Plzně od roku 775 až 1870 . Plzeň.

HUML, V., 1995: Rudolfínská lékárna Matyáše Borbonia na Koňském trhu očima archeologa. Praha.

HUS, M., 1990: Plzeňská akvamanilia - Aquamanilia aus Plzeň, AH 15, 397-403.

IGGERS, G. G., 2002: Dějepisectví ve 20. století. Praha.

KLÁPŠTĚ, J., 2003: Dějepis a archeologie: Příbuzenství jak se patří. In: Dějiny ve věku nejistot. Sborník k př́iležitosti 70. narozenin Dušana Třeštíka, 97-109. Praha.

KLÁPŠTĚ, J., ed., 2002: Archeologie středověkého domu v Mostě (čp. 226) - The archaeology of a medieval House (No. 226) in Most. Mediaevalia archaeologica 4. Praha.

KOLÁŘ, M.-SEDLÁČEK, A., 1902: Českomoravská heraldika I. Část všeobecná. Praha.

KRAJÍC, R. a kol., 1998: Dům pasíře Prokopa v Táboře. Archeologický výzkum odpadní jímky v domě čp. 220. Tábor.

MACHÁČEK, F., 1931: Dvě studie k dějinám Plzně a Plzeňska. Plzeň.

NECHVÁTAL, B., 1976: Středověká studna v Plzni - Solní ulici. Archeologické studijní materiály 12. Praha.

- 1984: Nálezy středověkých dlaždic v západních Čechách - Funde mittelalterlicher Fliesen in Westböhmen, AH 9, 247-261.

NEUGEBAUER, W. 1965: Der Burgwall Alt-Lübeck. Geschichte, Stand und Aufgaben der Forschung. Lübeck.

NEUSTUPNÝ, E., 2002: Archeologie a historie. In: Archeologie nenalézaného. Sborník přátel, kolegů a žáků k životnímu jubileu Slavomila Vencla, 141-152. Dobrá Voda u Pelhřimova.

NOVÁČEK, K., 2000: Středověký dům v Plzni. Archeologický výzkum parcely v Sedláčkově ul. 1 (čp. 187), SZM - Historie XV, 5-66.

NOVÁČEK, K.-STOČES, J.-ŠIROKÝ, R.-WASKOVÁ, M., 2014: Počátky Nové Plzně a její vývoj do husitství. In: Dějiny města Plzně I. Do roku 1788, 124-186. Plzeň.

NOVÁČEK, K.-ŠIROKÝ, R., 2004: Prvních sto let. Počátky Nové Plzně z pohledu archeologie, Minulostí Západočeského kraje XXXIX, 7-51.

NOVOTNÝ, V., 1912: České dějiny I. Praha.

ORNA, J., 2000: Nálezy středověkých dřevěných předmětů z Plzně. Katalog. CD-ROM. Plzeň.

- 2002: Středověký keramický zvonek z Plzně, ZSM - Historie XVI, 182-184.

- 2005: Gotické a renesanční kachle ve sbírkách Západočeského muzea v Plzni. Plzeň.

- 2006: Drobná stř̌edověká figurální keramická plastika z Plzně, Muzejní a vlastivědná práce. Časopis Společnosti přátel starožitností, č. 3-4, 206-208.

ORNA, J. a kol., 2011: Keramická produkce města Plzně v období 14. a 15. století. Plzeň.

ORNA, J.-DUDKOVÁ, V., 2012: Archeologické doklady obléhání Plzně husity - Archäologische Belege über die Belagerung Pilsens durch die Hussiten, AH 37, 165-174.

PROFANTOVÁ, N.-PROFANT, M., 2003: Archeologie a historie aneb ,,jak vykopávat dějiny?“. In: Dějiny ve věku nejistot. Sborník k př́ležitosti 70. narozenin Dušana Třeštíka, 239-250. Praha.

RUSEK, V.-SMEČKA, V., 2000: České lékárny. Praha.

RYBIČKA, A., 1874: Erbovní rodiny Plzenské, PA XX, 261-274.

SCHNEIDERWINKLOVÁ, P. a kol., 2008: Raně novověká studna z Plzně, Perlové ulice - výpověd' archeologických a environmentálních pramenů - A Renaissance cesspit from Plzeň, Perlová Street - results of archaelogical and environmental analyses. In: Ve službách archeologie VIII/2, 175-196. Brno.

SCHNEIDERWINKLOVÁ, P. 2009: The relationship between vessel forms and the main pramic classes from well no. 03 in Perlová Street in Plzeň - Vazba tvarů nádob na hlavní keramickou produkci ze studny 03 v Perlové ulici v Plzni - Verhältnis der Gefäßformen zur Hauptkeramikproduktion aus Brunnen 03 in der Perlová-Gasse in Pilsen. In: Studies in Post-Medieval Archaeology 3, 199-206. Praha.

STRNAD, J., 1898: Kašpar Kropáč z Kozince, Časopis Musea království Českého LXXII, $263-282$.

- 1909: Nejstarší místopis Plzně do válek husitských, Sborník městského historického musea v Plzni I, 54-87.

SVOBODNÝ, P.-HLAVÁČKOVÁ, L. 2004: Dějiny lékařství v českých zemích. Praha. 
TIDOW, K., 1989: Herstellung und Verbreitung von Gewebebindungen bei norddeutschen Wollgeweben des Mittelalters aufgrund von Neufunden. In: Lübecker Schriften zur Archäologie und Kulturgeschichte 16. Baugeschichte und Handwerk auf dem Lübecker Stadthügel, 335-357. Bonn.

TŘEŠTÍK, D., 2001: K poměru archeologie a historie, AR LIII, 357-361.

WINTER, Z., 1890: Kulturní obraz českých měst. Život veřejný v XV. a XVI. věku I. Praha.

\section{Zusammenfassung}

\section{Möglichkeiten, Gegenstände aus Pilsner Abwassergruben bestimmten Bürgern der Stadt zuzuordnen}

Aus dem reichen, in Pilsen aus Abwassergruben gewonnenen Fundbestand ist es gelungen, neun Fälle von Artefakten oder Gruppen von Artefakten zu bestimmen, die mit dem Besitzer, bzw. dem Bewohner eines Hauses in einen direkten Zusammenhang gebracht werden können.

Die Analyse dieser positiven Feststellungen ermöglichte eine Definition von Kategorien, welche die Identifikation einer konkreten Person möglich machen. Eine von ihnen sind Heraldikzeichen, die in der Umgebung von Pilsen besonders für Wappenbürger im 16. und 17. Jahrhundert verwendet wurden. Leider konnte bislang lediglich eine Keramikskulptur mit dem Wappen von Kašpar Kropáč von Kozinec erfasst werden.

Eine weitere Kategorie bildet die zum Betreiben eines Handwerks oder Gewerbes erforderlich Ausstattung. Ein Gewerbe, und zwar die Ausübung des Berufs eines Arztes oder Apothekers, konnte einschließlich der Bestimmung von konkreten Personen bei der Abwassergrube von Konskriptionsnummer 289 festgestellt werden. Ein Beleg für das Holzverarbeitungshandwerk ist ein in der Abwassergrube 1 bei Konskriptionsnummer 73 gefundenes Messer einer Drehbank.

Am häufigsten zur Bestimmung einer konkreten Person verwendbar war Produktionsabfall, besonders dann Belege für Schuster- und Sattlertätigkeiten. Die Analyse der mit Produktionsabfall zusammenhängenden Feststellungen deutete an, dass es möglich ist, dass auch Textilfunde mit den lederverarbeitenden Handwerken zusammenhängen könnten.

Die oben genannten Feststellungen konnten nicht ohne ein Zusammenwirken und einen Vergleich mit den schriftlichen Quellen gemacht werden. Gerade ihr Fehlen stellte die deutlichste Komplikation bei dem Bemühen dar, einen archäologischen Fund einer konkreten Person zuzuordnen. $\mathrm{Zu}$ den weiteren Komplikationen zählt das Problem mit der Lokalisierung von Abwassergruben, was eine Folge dessen ist, dass sich die Parzellierung änderte und die Lage einer Grube bei der Grabung nicht genau bestimmt wurde sowie der Prozess des Deponierens von Abfall in den Gruben. Eine Grube konnte für die Bewohner von mehreren Häusern gedient haben, bei jedem von ihnen verliefen die Postdeponierprozesse anders ab, auch haben Personen sie nutzen können, die in den sog. Hinterhäusern zur Miete gewohnt haben (inquilini).

Die im Rahmen der vorliegenden Studie gemachten Feststellungen tragen besonders dazu bei, Erkenntnisse über die soziale Topographie der Königsstadt Pilsen im Spätmittelalter und der frühen Neuzeit zu gewinnen. In den genannten Beispiele haben die archäologischen Funde bestätigt, dass das Betreiben eines Handwerks oder eines Gewerbes in Immobilien stattfand, die sich im Besitz eines entsprechenden Handwerkers oder Gewerbetreibenden befanden, wodurch die positive Auswirkung eines Zusammenwirkens und Vergleichs von archäologischen und historischen Quellen nachgewiesen wurde, um Erkenntnisse über die Geschichte des Alltags einer spätmittelalterlichen und frühneuzeitlichen Stadt zu gewinnen.

Mgr. Jiří Orna, Západočeské muzeum v Plzni, Kopeckého sady 2, 30100 Plzeň, Česká republika, jorna@zcm.cz

Mgr. Veronika Dudková, Západočeské muzeum v Plzni, Kopeckého sady 2, 30100 Plzeň,

Česká republika,vdudkova@zcm.cz 